\title{
STRUCTURE AND ENCAPSIDATION OF TRANSMISSIBLE GASTROENTERITIS CORONAVIRUS (TGEV) DEFECTIVE INTERFERING GENOMES
}

\author{
Ana Méndez, Cristian Smerdou, Fátima Gebauer, Ander Izeta, and \\ Luis Enjuanes \\ Department of Molecular and Cellular Biology \\ Centro Nacional de Biotecnología \\ Campus Universidad Autónoma \\ Canto Blanco \\ Madrid 28049, Spain
}

\begin{abstract}
Serial undiluted passages were performed with the PUR46 strain of TGEV in swine testis (ST) cells. Total cellular RNA was analyzed at different passages after orthophosphate metabolic labeling. Three new defective RNA species of 24, 10.5, and $9.5 \mathrm{~kb}$ (DI-A, DI-B, and DI-C respectively) were detected at passage 30 , which were highly stable and significantly interfered with helper mRNA synthesis in subsequent passages. By Northern hybridization DIs A, B, and C were detected in purified virions at amounts similar to those of helper RNA. Standard and defective TGEV virions could be sorted in sucrose gradients, indicating that defective and full-length genomes are independently packaged. cDNA synthesis of DI-B and DI-C RNAs was performed by the reverse transcription-polymerase chain reaction (RT-PCR) to give four fragments in each case. Cloning and sequencing of the DI-C PCR products showed that the smallest DI particle comprises $9.5 \mathrm{~kb}$ and has 4 discontinuous regions of the genome. It contains $2.1 \mathrm{~kb}$ from the $5^{\prime}$-end of the genome, about $7 \mathrm{~kb}$ from gene $1 \mathrm{~b}$, the first 24 nucleotides of the S gene, 12 nucleotides of ORF 7, and the $0.4 \mathrm{~kb}$ of the UTR at the $3^{\prime}$-end.
\end{abstract}

\section{INTRODUCTION}

In recent years, the assembly of full-length, infectious cDNA clones of a number of positive-strand RNA viruses has greatly facilitated molecular genetic analyses of viral proteins and cis regulatory elements ${ }^{9}$. The large size of coronavirus genomes (26 to $\left.31 \mathrm{~kb}\right)$, 
however, has been a constraint on this approach. The generation of coronavirus defective RNAs, containing the cis signals required for replication but dependent on viral replicase functions to be supplied in trans, was exploited to circumvent this limitation. cDNA constructs of small Mouse Hepatitis Virus (MHV) defective RNAs have been successfully employed to define $c i s$-acting signals required for replication ${ }^{2,4}$, transcription ${ }^{2,4,11,13}$ and encapsidation of the virus ${ }^{6}$. Their manipulation has also permitted the introduction of site-specific mutations into the $3^{\prime}$-end of the genome by homologous RNA recombination ${ }^{6}$, 12,7 , and the engineering of chimeric viruses expressing heterologous genes ${ }^{4}, 3$. Defective interfering genomes have, in addition, a growing potential in protection against viral disease.

To date, coronavirus defective RNAs have been reported only for $\mathrm{MHV}^{5}$ and Infectious Bronchitis Virus (IBV) ${ }^{8}$. In this chapter we report the characterization, cloning and sequencing of naturally occurring defective RNAs of TGEV which are replicated and packaged into virus particles.

\section{MATERIALS AND METHODS}

\section{Virus and Cells}

The plaque-cloned PUR46 strain of TGEV was used to perform the serial undiluted passages in ST cells.

\section{Radiolabeling of Intracellular Viral RNA and Agarose Gel Electrophoresis}

Briefly, ST cell monolayers were infected with viruses from different passages at a multiplicity of infection of 10 and labeled with ${ }^{32} \mathrm{Pi}$ from 6 to 9 hours post infection in the presence of $2.5 \mu \mathrm{g} / \mathrm{ml}$ of actinomycin D. Cytoplasmic extracts were prepared by lysing the cells in TSM buffer $\left(0.15 \mathrm{M} \mathrm{NaCl}, 0.01 \mathrm{M}\right.$ Tris-hydrochloride [pH 7.6], $\left.5 \mathrm{mM} \mathrm{MgCl}_{2}\right)$ containing $0.2 \%$ Nonidet $\mathrm{P}-40$, and pelleting nuclei by centrifugation at $13000 \mathrm{~g}, 30 \mathrm{sec}$. RNA was isolated by the addition of urea-SDS lysis buffer (1.5\% SDS, $15 \mathrm{mM}$ EDTA, $0.24 \mathrm{M}$ $\mathrm{NaCl}, 0.04 \mathrm{M}$ Tris-hydrochloride [pH 7.6], 8M urea) and phenol-chloroform extraction. Gel electrophoresis was conducted after denaturation of RNA with formaldehyde.

\section{Purification of Virions through Sucrose Layers}

Virus was harvested at 12 hpi from 12 roller bottles which had been infected with PUR46p41 at m.o.i. 10. Virus was clarified, and divided into two portions. One of them was underlaid with $15 \%$ sucrose and the other with $31 \%$ sucrose. Samples were centrifuged at $84000 \mathrm{~g}$ for 2 hours. RNA was extracted from pelleted virions in each case.

\section{Separation of Virions in a Linear Sucrose Gradient for RNA Extraction}

Virus was harvested at $12 \mathrm{hpi}$ from 12 roller bottles which had been infected with PUR46p41 at m.o.i. 10. Virus harvests were clarified and concentrated by pelleting the virus through $15 \%$ sucrose. Pelleted virus was resuspended in TEN-Tween $20(0.01 \mathrm{M}$ Tris- $\mathrm{HCl}$ $\mathrm{pH}=7.4,1 \mathrm{mM}$ EDTA, $1 \mathrm{M} \mathrm{NaCl}, 0.2 \% \mathrm{v}: \mathrm{v}$ Tween 20 ) and placed on top of a $15-42 \%$ linear sucrose gradient. Sample was centrifuged at $84000 \mathrm{~g}$ for two hours. After fractionation of the gradient, each fraction was diluted and virions were pelleted by centrifugation in the 
above conditions. RNA from virions in each fraction was extracted and analyzed by Northern blot.

\section{RT-PCR Amplification of DI-B and DI-C RNAs}

DI-B and DI-C RNAs from purified virions from passage 41 were amplified by RT-PCR in four separate fragments. As the complete sequence of TGEV genome was not known, primers were derived from high homology sequence regions among HCV 229E and FIPV. Virus sequences were kindly provided by S.Siddel and R. de Groot, respectively.

\section{RESULTS}

\section{Detection of Defective RNAs in ST Cells}

PUR46 strain of TGEV was passaged undiluted 45 times in ST cells. RNAs induced by TGEV infection at several passage levels were analyzed in a denaturing gel after $\left[{ }^{32} \mathrm{P}\right]$ orthophosphate metabolic labeling. At passage 30 three new subgenomic RNAs of 24, 10.5, and $9.5 \mathrm{~kb}$ (DI-A, DI-B and DI-C) were detected (Fig. 1). These defective RNAs persisted in increasing amounts during 15 subsequent passages in ST cells, significantly interfering with helper genomic and subgenomic RNA synthesis. When ten more undiluted passages

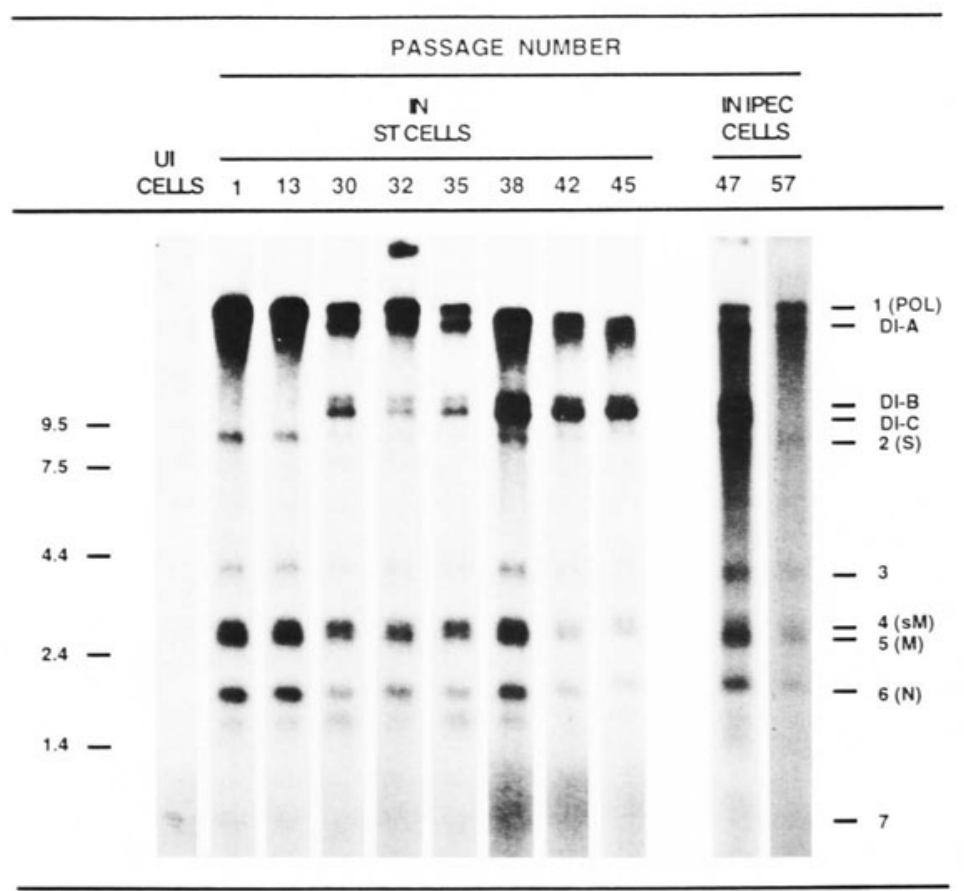

Figure 1. Electrophoretic analysıs of metabolically labeled TGEV RNAs Cytoplasmic RNA at different passage levels was extracted and separated in denaturıng agarose gels after $\left[{ }^{32} \mathrm{P}\right]$ orthophosphate metabolic labeling Passage numbers are indicated at the top of each lane Bars on the right show TGEV mRNAs and DIs, and bars on the left the position of RNA molecular weight markers (GibcoBRL) Three new RNA species of 24,105 and $9.5 \mathrm{~kb}$ (DI-A, B, and C) were detected at passage 30 and persisted at least after 15 additional passages in ST cells DI-B and DI-C were lost after 10 undiluted passages in a different cell line (IPEC) 
A

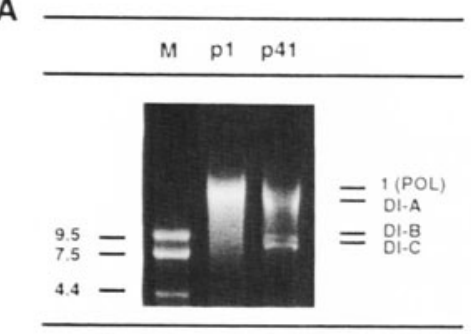

B

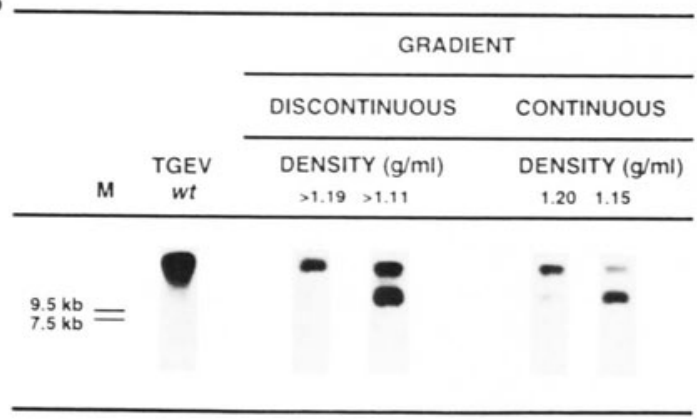

Figure 2. Analysis of RNA from passage 41 purified virions. A. Virions from passages 1 and 41 were purified by centrifugation through $15 \% \mathrm{w} / \mathrm{v}$ sucrose. RNA was extracted and analyzed in an ethidium bromide stained agarose gel. At passage 41 defective RNAs A, $\mathrm{B}$, and $\mathrm{C}$ were detected in addition to $w t$ RNA. B. Virions were purified by centrifugation through $31 \% \mathrm{w} / \mathrm{v}$ or $15 \% \mathrm{w} / \mathrm{v}$ sucrose cushions, or through a continuous sucrose gradient (15\%-42\%). RNA from pelleted virions was extracted, separated in denaturing agarose gels, and hybridized to a leader specific probe. Only wt genomes were detected in virions with densities $>1.19 \mathrm{~g} / \mathrm{ml}$, but defective RNAs were also present in virions with lower densities $(>1.11 \mathrm{~g} / \mathrm{ml})$. Both types of virions, standard and defective, could be sorted in a continuous gradient. RNA from virions at passage 1 was used as a marker.

were performed on intestinal epithelial cells (IPEC), only DI-A persisted, whereas DIs B and $\mathrm{C}$ were lost. This suggests that host cell factors may affect the stability of defective particles.

To determine whether defective RNAs had the $5^{\prime}$ and $3^{\prime}$ end of the genome Northern hybridization was performed with $\left[{ }^{32} \mathrm{P}\right]$-labeled oligonucleotides complementary to the leader and the 3'-UTR sequences. Both oligonucleotides hybridized to all wt mRNAs and also detected DIs A, B, and C. As a first approach to study which genomic sequences were present in the DIs, total RNA from ST-infected cells was also probed with oligonucleotides mapping in S, M, and N structural protein genes. None of them detected the DIs. These results indicate that DIs A, B, and C contain genomic 5' and $3^{\prime}$ sequences, but lack structural genes (data not shown).

\section{Packaging of Defective RNAs}

To study whether defective RNAs were encapsidated, virions from passages 1 and 41 were partially purified by centrifugation through a $15 \% \mathrm{w} / \mathrm{v}$ sucrose cushion. RNA from pelleted virions was extracted in each case and analyzed in an ethidium bromide gel. (Fig. 2A). Defective RNAs A, B, and C were detected in addition to full-length RNA in virions from passage 41 .

To determine whether full-length and defective RNAs were independently packaged, centrifugation through different density sucrose cushions as well as continuous sucrose gradients were used to purify virions. RNA extracted from purified virions was analyzed by Northern blot using a leader specific probe (Fig. 2B). Only the $w t$ genome was detected when $31 \% \mathrm{w} / \mathrm{v}$ sucrose $(1.19 \mathrm{~g} / \mathrm{ml})$ was used. However when the sucrose density was decreased to $15 \% \mathrm{w} / \mathrm{v}(1.11 \mathrm{~g} / \mathrm{ml})$ both the full-length and the defective RNAs were present. These data indicate that DI RNAs are packaged in defective virions, which differ in density from the standard ones. An almost complete separation of $w t$ and defective virions was achieved in continuous sucrose gradients (15\%-42\%). Lower fractions (density $1.20 \mathrm{~g} / \mathrm{ml}$ ) were enriched in standard virions, while defective virions were concentrated in upper fractions (density $1.15 \mathrm{~g} / \mathrm{ml})$. 


\section{Cloning and Sequencing of DIs B and C}

DIs B and C RNA from passage 41 purified virions were used together as templates for cDNA synthesis by RT-PCR. Due to their large size DIs could not be amplified using primers specific for the ends of the genome. Four different sets of primers were designed to amplify DI-B and C RNAs in four overlapping fragments (I, II, III, and IV from the $5^{\prime}$ to the $3^{\prime}$ end). PCR products were cloned. Fragments I and II were common to DIs B and C, but clones of two different sizes were found for fragments III and IV which account for the difference in length of DIs B and C (data not shown). The DI-C four fragments were sequenced from at least two independent RT-PCR reaction clones.

The genetic structure of DI-C was determined and is summarized in Fig. 3. It has about one third of the genome length and includes: i) $2.1 \mathrm{~kb}$ from the $5^{\prime}$-end; ii) ORF1b almost complete but with a small internal deletion; iii) the first 24 nucleotides of S gene; iv) the last 12 nucleotides of the ORF 7; and, v) the $3^{\prime}$-end UTRs. Two main deletions remove most of ORF la and the structural and $3^{\prime}$ non structural protein genes. Preliminary data indicate that DI-B has a similar genetic structure than DI-C, but differs in the size and the precise location of the main 3'-end deletion and the internal deletion in ORF $1 \mathrm{~b}$ (data not shown).

\section{DISCUSSION}

The frequency of DI particle generation in TGEV is lower than in MHV. While in MHV defective RNAs are easily detected after a few passages, in TGEV novel RNA species were only identified at late passages in one out of four isolates assayed. TGEV strains PUR46-MAD, HOL87, and PUR46mar1CC12 were passaged 35 times in ST cells at a multiplicity of infection close to $100 \mathrm{PFU} /$ cell. An uncloned isolate, PUR46SW37CC4, was serially passaged in IPEC cells ${ }^{10,1}$. Defective RNAs were only detected in PUR46-MAD

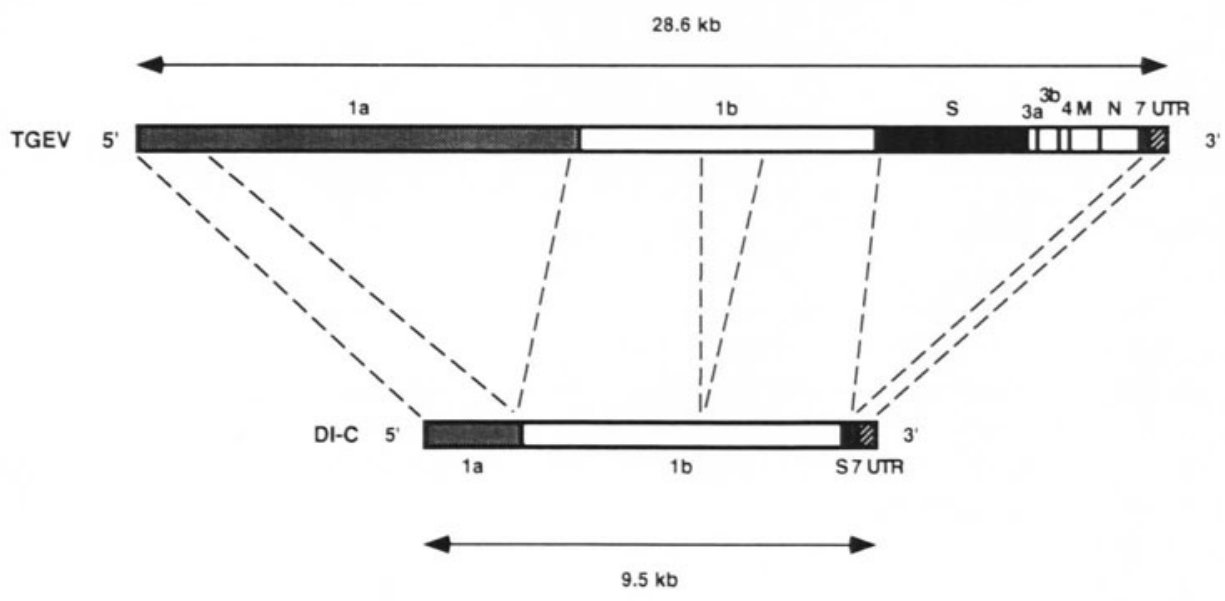

Figure 3. Diagram summarizing the structure of TGEV DI-C. DI-C, the smallest TGEV defective RNA isolated, contains 4 discontinuous regions of the TGEV genome. It comprises $2.1 \mathrm{~kb}$ from the $5^{\prime}$ end, almost complete ORF $1 \mathrm{~b}$ including the la-lb overlapping region, the beginning of $\mathrm{S}$ gene, incomplete ORF 7 , and the UTRs. 
strain after 30 passages. This is in contrast to what has been described in MHV, where seven JHM defective RNAs of different size were characterized from passage 3 through 22 in DBT cells.

In addition, MHV defective RNAs naturally evolve early after generation, whereas TGEV defective RNAs, once generated, were highly stable. DIs A, B, and C persisted along 15 passages in ST cells, and no changes in size or the generation of novel RNA species were observed. This difference in the rate of generation and evolution of naturally occurring DIs in both viruses may be due to a more accurate replication of TGEV RNA.

Interference of standard TGEV-PUR46 replication by DI particles was observed after passage 30. The levels of genomic and subgenomic RNAs were reduced from passage 32 to 45 , as the defective RNAs were enriched. DI-C $(9.5 \mathrm{~Kb})$ is the most abundant RNA at late passages. One possible mechanism of interference is through competition between standard virus RNA and DI RNA for the viral polymerase. There may be other reasons for the selective advantage of DIs, such as secondary or tertiary RNA structure, or encapsidation efficiency.

The present study clearly indicates that DI and standard RNAs are independently encapsidated. It can not be excluded that more than one DI genome is encapsidated per virion, although the clear density difference between virions with full length or defective genomes suggests that only one or two RNA molecules are present in defective virions.

Cloning and sequencing of DIs B and $\mathrm{C}$ revealed that they comprise 4 discontinuous regions of the TGEV genome. They are similar in primary structure to both MHV and IBV defective interfering RNAs, but their length and structure make them more comparable to CD-91, a defective genome of $9.1 \mathrm{~kb}$ isolated from IBV. However, DIs B and C include most of gene $1 \mathrm{~b}$, including the $3^{\prime}$ end of gene $1 \mathrm{~b}$ that DI CD-91 from IBV lacks. In this region of MHV a 61-nt packaging signal has been identified. The precise location of TGEV RNA encapsidation signal is not known.

The $5^{\prime}$ end of gene la region of DIs B and C $(2.1 \mathrm{~kb})$ is larger than the IBV gene la region present in DI CD-91 $(1.1 \mathrm{~kb})$, but also lacks the $0.2-\mathrm{kb}$ region of the MHV gene 1a that is located about $3.2 \mathrm{~kb}$ from the $5^{\prime}$ end of the MHV genome and which has been found essential for MHV DI replication in some strains. This region may not be required for TGEV replication, or a homologous region may be located elsewhere. The ORF 1a-1b overlapping region was maintained in both $\mathrm{DI} B$ and $\mathrm{C}$, including the pseudoknot motif necessary for ribosomal frameshift. At present, it is not known if this motif may contribute to the fitness of these long DIs.

\section{ACKNOWLEDGMENTS}

This work has been supported by grants from the Consejo Superior de Investigaciones Científicas, the Comisión Interministerial de Ciencia y Tecnología, Instituto Nacional de Investigaciones Agrarias, La Consejería de Educación y Cultura de la Comunidad de Madrid, and Laboratorios Sobrino (Cyanamid) from Spain, and the European Communities (Projects Science and Biotech). Ana Méndez and Ander Izeta received fellowships from the Comunidad de Madrid and Gobierno Vasco.

\section{REFERENCES}

1 Gebauer, F., Posthumus, W A P, Correa, I , Suñe, C., Sanchez, C M., Smerdou, C , Lenstra, J. A., Meloen, R., Enjuanes, L Residues involved in the formation of the antigenic sites of the S protein of transmissible gastroenteritıs coronavirus Virology 1991, 183: 225-238 
$2 \mathrm{~K} ı \mathrm{~m}, \mathrm{Y} \mathrm{N}$, Laı, M M C , Makıno, S Generatıon and selectıon of coronavırus defectıve interferıng RNA with large open reading frame by RNA recombination and possible editıng Vırology 1993, 194 244-253

$3 \mathrm{Liao}, \mathrm{C}-\mathrm{L}$, La1, M M C The requirement of $5^{\prime}$-end genomic sequence as an upstream cis-actıng element for coronavirus subgenomic mRNA transcription J Virol 1994, 68 4727-4737

4 Lin, Y J , Lal, M M C Deletion mapping of a mouse hepatitıs virus defective interferıng RNA reveals the requirement of an internal and discontıguous sequence for replication J Virol 1993, 67 6110-6118

5 Makıno, S, Fujıka, N, Fujıwara, K Structure of the intracellular viral RNAs of defective interfering particles of mouse hepatitis virus J Virol 1985, 54 329-336

6 Makıno, S, Yokomorı, K, La1, M M C Analysıs of efficiently packaged defectıve interferıng RNAs of murıne coronavirus - localızation of a possible RNA-packaging signal J Virol 1990, 64 6045-6053

7 Masters, P S , Koetzner, C A, Kerr, C A, Heo, Y Optımızation of targeted RNA recombination and mapping of a novel nucleocapsid gene mutation in the coronavirus mouse hepatitis virus J Virol 1994, 68 328-337

8 Penzes, Z, Tibbles, K, Shaw, K, Britton, P, Brown, T D K, Cavanagh, D Characterization of a rephicating and packaged defectıve RNA of avian coronavirus infectious bronchitıs virus Vırology 1994, $203 \quad 286-293$

9 Racaniello, V R, Baltımore, D Cloned polıovirus cDNA is infectious in mammalıan cells Science 1981, 214 916-919

10 Sanchez, C M, Jimenez, G , Laviada, M D , Correa, I, Suñe, C, Bullıdo, M J, Gebauer, F, Smerdou, $\mathrm{C}$, Callebaut, P, Escribano, J M, Enjuanes, L Antıgenıc homology among coronaviruses related to transmissible gastroenteritıs virus Virology 1990, 174 410-417

11 Van der Most, R G, De Groot, R J, Spaan, W J M Subgenomic RNA synthesis directed by a synthetic defective interfering RNA of mouse Hepatitis virus a study of Coronavirus transcription initiation $J$ Virol 1994, 68 3656-3666

12 Van der Most, R G, Heijnen, L, Spaan, W J M, Degroot, R J Homologous RNA recombınation allows efficient introduction of site-specific mutations into the genome of coronavirus MHV-A59 via synthetic coreplicatıng RNAs Nuc Ac Res 1992, 20 3375-3381

13 Zhang, X, Liao, C L , La1, M M C Coronavirus leader RNA regulates and initiates subgenomic mRNA transcription both in trans and in cls J Virol 1994, 68 4738-4746 